\title{
Investigation of different sodium hypochlorite volumes, concentrations and times of irrigation in endodontic therapy: a systematic review
}

Investigação de diferentes volumes, concentrações e tempos de irrigação do hipoclorito de sódio na terapia endodôntica: uma revisão sistemática

Investigación de diferentes volúmenes, concentraciones y tiempos de irrigación de hipoclorito de sodio en la terapia endodóntica: una revisión sistemática

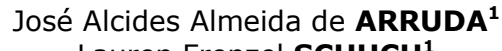

${ }^{I}$ Department of Oral Surgery, Pathology and Clinical Dentistry, School of Dentistry, Federal University of Minas Gerais (UFMG), 31.270-901, Belo Horizonte, MG, Brazil ${ }^{2}$ Department of Oral Pathology and Medicine, School of Dentistry, University of Pernambuco (FOP-UPE), 54.753-220, Camaragibe, PE, Brazil

\begin{abstract}
Although the sodium hypochlorite $(\mathrm{NaOCl})$ solution has been part of the endodontic arsenal for more than one century, current investigations have been unable to determine which $\mathrm{NaOCl}$ volume and concentration or which time of application are able to dissolve organic matter without weakening the dental structure during the phase of biomechanical preparation of the root canal. Thus, the objective of the present study was to conduct a systematic literature review with no restriction of publication year or language in order to resolve these questions. The search strategy included the following databases: PubMed, LILACS, Web of Science and ClinicalTrials.gov, and only in vivo human clinical trials were included in the final review. After the removal of duplicates, the systematic literature review yielded 3,717 articles. Of these, 3,685 were excluded after applying the exclusion criteria (ex vivo studies, animal studies, cell-culture studies, narrative review, and studies with no available full texts). A total of 32 full-text articles were assessed for eligibility. After evaluating the full text, all articles were excluded for different reasons. No studies fulfilled our inclusion criteria. This review was unable to answer what time of irrigation, concentration or volume of $\mathrm{NaOCl}$ solution can be of maximum effectiveness in endodontic treatment without producing significant changes in the mechanical properties of dentin. Thus, future human clinical studies are needed in order to resolve these questions.
\end{abstract}

Descriptors: Endodontics; Sodium Hypochlorite; Review.

\section{Resumo}

Embora a solução de hipoclorito de sódio $(\mathrm{NaOCl})$ tem feito parte do arsenal endodôntico por mais de um século, as investigações atuais têm sido incapazes de determinar qual volume de $\mathrm{NaOCl}$ e concentração ou qual tempo de aplicação são capazes de dissolver a matéria orgânica sem enfraquecer a estrutura dentária durante a fase de preparação biomecânica do canal radicular. Assim, o objetivo do presente estudo foi realizar uma revisão sistemática da literatura, sem restrição de ano de publicação ou idioma para resolver estas questões. A estratégia de pesquisa incluiu os seguintes bancos de dados: PubMed, LILACS, Web of Science e ClinicalTrials.gov. Somente estudos in vivo foram incluídos na revisão final. Após a remoção de duplicatas, a revisão sistemática da literatura ofereceu 3.717 artigos. Destes, 3.685 foram excluídos depois dos critérios de exclusão aplicados (estudos ex vivos, estudos em animais, estudos de cultura de células, revisão narrativa e estudos com textos completos indisponíveis). Um total de 32 artigos com texto completo foram avaliados para elegibilidade. Depois de avaliar o texto completo, todos os artigos foram excluídos por razões diferentes. Não existiu estudos cumpridos nossos critérios de inclusão. Esta revisão foi incapaz de responder em que tempo de irrigação, concentração ou volume de solução de $\mathrm{NaOCl}$ podem apresentar máxima eficácia no tratamento endodôntico sem produzir mudanças significativas nas propriedades mecânicas da dentina. Assim, futuros estudos clínicos em humanos são necessários para responder essa pergunta.

Descritores: Endodontia; Hipoclorito de Sódio; Revisão.

\section{Resumen}

A pesar de que la solución de hipoclorito de sodio $(\mathrm{NaOCl})$ ha sido parte del arsenal endodóntico por más de un siglo, las investigaciones actuales no han podido determinar el volumen exacto del $\mathrm{NaOCl}$, concentración y el tiempo de aplicación capaces de disolver la materia orgánica sin debilitar la estructura dental durante la fase de preparación biomecánica del conducto radicular. El objetivo del presente estudio fue realizar una revisión sistemática de literatura, sin restricción de año de publicación o de idioma para responder estas preguntas. La estrategia metodológica utilizada fué consultar las siguientes bases de datos: PubMed, LILACS, Web of Science y ClinicalTrials.gov. Y se incluyeron solamente estudios in vivo en la presente revisión. Después de la eliminación de duplicados, la revisión sistemática tuvo 3.717 artículos. De estos, 3.685 fueron eliminados según los criterios de exclusión (estudios ex vivos, estudios en animales, estudios de cultivo de células, revisión narrativa y estudios con textos completos no disponibles). Un total de 32 artículos completos fueron escogidos y evaluados. Después de evaluar los textos completos, todos los artículos tuvieron que excluirse por diferentes razones. No fueron encontrados estudios cumpliendo con nuestros criterios de inclusión. Esta revisión no fue capaz de responder en qué tiempo de irrigación, concentración o volumen de solución de $\mathrm{NaOCl}$ puede presentar máxima eficacia en el tratamiento endodóntico sin alterar significativamente las propiedades mecánicas de dentina y disolver la matéria orgánica de los conductos radiculares. Siendo así, los futuros estudios clínicos en humanos se hacen necesarios para responder a nuestra pregunta.

Descriptores: Endodoncia; Hipoclorito de Sodio; Revisión.

\section{INTRODUCTION}

Chemical and mechanical preparation is used for root canal cleaning, expansion and modeling. These steps essentially involve filing of dentinal walls with the aid of endodontic instruments ${ }^{1}$ plus the action of irrigating chemical substances on the components of the root canal system ${ }^{2}$ for residue removal and for an antimicrobial action ${ }^{3,4}$.

An important challenge is the choice of the chemical substance to be used since, so far, none of them has proved to have ideal qualities needed for the disinfection of root canals ${ }^{5}$. However, sodium hypochlorite $(\mathrm{NaOCl})$ is the auxiliary substance 
universally chosen by clinicians and endodontists because of its ability to neutralize the content of toxic-necrotic material and to dissolve organic matter in the root canals ${ }^{6-8}$. The recommended $\mathrm{NaOCl}$ concentrations range from 0.5 to $6 \%$, but there is no consensus about $\mathrm{NaOCl}$ concentration or volume or time of irrigation in clinical practice ${ }^{9}$.

The properties of $\mathrm{NaOCl}$ for the dissolution and degradation of organic matter are directly proportional to its concentration and volume which, when elevated, may be toxic and favor dentin fragility after endodontic treatment ${ }^{10}$. Although many studies have assessed the development of this fragility such as root fractures related to excessive expansion of the root canals, pressure transmission to canal walls during shaping and obturation, presence of a post or an isthmus, and occlusal overload by masticatory forces, ${ }^{11,12}$ few investigations have concentrated on the use of $\mathrm{NaOCl}$ and its possible deleterious action on root dentin ${ }^{12}$.

For these reasons, clinicians and endodontists are concerned about the ideal concentration and volume of $\mathrm{NaOCl}$ and the time needed for its action during the biomechanical preparation of root canals in order to dissolve and disinfect organic matter without weakening the dental root. On the basis of the above considerations, the objective of the present study was to conduct a systematic literature review aiming at the resolution of these questions.

\section{MATHERIAL AND METHOD}

- Information sources and search strategy

This study followed the PRISMA guidelines for systematic reviews ${ }^{13}$ and the PICO strategy (Patient, Intervention, Comparison and Outcome) was used to formulate an adequate research question. Table 1 presents the four components of this strategy for the present study. The review protocol was registered with PROSPERO (registration No. CRD 42017054317).

A systematic review with no restriction of publication year or language was carried out. The search strategy included the following databases: PubMed (National Library of Medicine), LILACS (via BVS, Latin America), Web of Science (Thomson Reuters), and ClinicalTrials.gov and the reference list of selected articles. The search was undertaken in September 2017. The following search criteria were applied to the PubMed, BVS and Web of Science databases: ( $\mathrm{NaOCl}$ OR sodium hypochlorite) AND (endo* OR root canal). For the ClinicalTrials.gov database, the term sodium hypochlorite was applied in the search field "other terms".

\section{- Eligibility criteria and study selection}

Articles had to be in vivo human clinical trials to be included in the final review. The exclusion criteria were ex vivo studies, animal studies, cell-culture studies, narrative review, and studies with no available full texts.

Studies were selected by two independent authors (G.C. and A.P.) and kappa scores were calculated. First, titles and abstracts were screened for inclusion. Those whose titles clearly showed that they were in vitro or animal studies were excluded in this first stage. If there was insufficient information in the abstract the full texts were retrieved and read for possible inclusion. Any disagreements regarding the articles included in the final review were resolved by a third investigator (P.M.R.M.J.) with experience in the subject. The Mendeley Desktop Software (1.17.11, Mendeley LTD., London, UK) was used.

○ Risk of bias assessment and data analysis

The "Risk of bias tool" of the Cochrane Collaboration was used to assess the risk of bias of the studies included if randomized clinical trials fulfilling the inclusion criteria were found. The Review Manager 5.3 software (Copenhagen: The Nordic Cochrane Centre, The Cochrane Collaboration, 2014) was used to perform metaanalysis if appropriate.

\begin{tabular}{ll} 
Table 1. PICO strategy used to formulate the research question \\
\hline \multirow{3}{*}{ Population } & $\begin{array}{l}\text { Permanent vital tooth } \\
\text { Permanent teeth with necrotic pulp } \\
\text { Teeth with periapical lesions }\end{array}$ \\
& $\begin{array}{l}\text { Irrigation with sodium hypochlorite at different } \\
\text { concentrations }\end{array}$ \\
Intervention & $\begin{array}{l}\text { Irrigation with another irrigation solution or with } \\
\text { different sodium hypochlorite concentrations }\end{array}$ \\
& $\begin{array}{l}\text { Volume } \\
\text { Irrigation time }\end{array}$ \\
& $\begin{array}{l}\text { Disinfection of root canal systems } \\
\text { Dissolution of organic matter } \\
\text { Outcome }\end{array}$ \\
& Tooth structure fragility \\
\hline
\end{tabular}

\section{RESULTS}

Inter-examiner agreement based on kappa was 0.83. After duplicate removal, the systematic literature review yielded 3,717 articles, 3,685 of which were excluded after applying the exclusion criteria. A total of 32 full-text articles were assessed for eligibility (Table 2). After evaluating the full-text, all articles were excluded for different reasons.

The flowchart of study selection is illustrated in figure 1. Nineteen of them only assessed one $\mathrm{NaOCl}$ concentration, six were in vitro, three were reviews, one was an ex vivo study, one was an animal study, one used irrigation with chlorhexidine, and one was a letter to the editor.

Therefore, no studies fullfilled our inclusion criteria. Also figure 2 shows flow chart about controlled clinical investigations involving young adult patients with anterior teeth showing radiographically visible endodontic lesions and two options of $\mathrm{NaOCl}$ treatment. 
Table 2. Articles excluded after full text evaluation and reasons for exclusion

\begin{tabular}{|c|c|}
\hline $\begin{array}{l}\text { Byström e Sundqvist }{ }^{4} \\
\text { Bacteriologic evaluation of the effect of o.5 percent sodium } \\
\text { hypochlorite in endodontic therapy }\end{array}$ & $\begin{array}{c}\text { Not selected } \\
\text { Only one NaOCl } \\
\text { concentration }\end{array}$ \\
\hline $\begin{array}{l}\text { Hand et al. }{ }^{14} \\
\text { Analysis of the effect of dilution on the necrotic tissue dissolution } \\
\text { property of sodium hypochlorite }\end{array}$ & $\begin{array}{l}\text { Not selected } \\
\text { Animal studies }\end{array}$ \\
\hline $\begin{array}{l}\text { Thé15 } \\
\text { The solvent action of sodium hypochlorite on fixed and unfixed } \\
\text { necrotic tissue }\end{array}$ & $\begin{array}{l}\text { Not selected } \\
\text { Only one } \mathrm{NaOCl} \\
\text { concentration }\end{array}$ \\
\hline $\begin{array}{l}\text { Ringel et al. }{ }^{16} \\
\text { In vivo evaluation of chlorhexidine gluconate solution and sodium } \\
\text { hypochlorite solution as root canal irrigants }\end{array}$ & $\begin{array}{c}\text { Not selected } \\
\text { Only one } \mathrm{NaOCl} \\
\text { concentration }(2.5 \%)\end{array}$ \\
\hline $\begin{array}{l}\text { Ercan }^{17} \\
\text { Antibacterial activity of } 2 \% \text { chlorhexidine gluconate and } 5.25 \% \\
\text { sodium hypochlorite in infected root canal: in vivo study }\end{array}$ & $\begin{array}{c}\text { Not selected } \\
\text { Only one } \mathrm{NaOCl} \\
\text { concentration }(5.25 \%)\end{array}$ \\
\hline $\begin{array}{l}\text { Siqueira et al. }{ }^{18} \\
\text { Bacteriologic investigation of the effects of sodium hypochlorite and } \\
\text { chlorhexidine during the endodontic treatment of teeth with apical } \\
\text { periodontitis }\end{array}$ & $\begin{array}{l}\text { Not selected } \\
\text { In vitro study }\end{array}$ \\
\hline $\begin{array}{l}\text { Estrela et al. }{ }^{19} \\
\text { Efficacy of sodium hypochlorite and chlorhexidine against } \\
\text { Enterococcus faecalis--a systematic review }\end{array}$ & $\begin{array}{l}\text { Not selected } \\
\text { Review }\end{array}$ \\
\hline $\begin{array}{l}\text { Fedorowicz e Sequeira } \mathrm{a}^{20} \\
\text { Efficacy of sodium hypochlorite and chlorhexidine against } \\
\text { Enterococcus faecalis--a systematic review }\end{array}$ & $\begin{array}{l}\text { Not selected } \\
\text { Letter to the Editor }\end{array}$ \\
\hline $\begin{array}{l}\text { Gomes et al. }{ }^{21} \\
\text { Comparison of } 2.5 \% \text { sodium hypochlorite and } 2 \% \text { chlorhexidine gel } \\
\text { on oral bacterial lipopolysaccharide reduction from primarily } \\
\text { infected root canals }\end{array}$ & $\begin{array}{c}\text { Not selected } \\
\text { Only one } \mathrm{NaOCl} \\
\text { concentration }(2.5 \%)\end{array}$ \\
\hline $\begin{array}{l}\text { Abbaszadegan et al. } .^{22} \\
\text { Comparison of antimicrobial efficacy of IKI and NaOCl irrigants in } \\
\text { infected root canals: an in vivo study }\end{array}$ & $\begin{array}{l}\text { Not selected } \\
\text { The same concentration o } \\
2.5 \% \mathrm{NaOCl}\end{array}$ \\
\hline $\begin{array}{l}\text { Bashetty } \mathrm{K}, \mathrm{Hegde}^{23} \\
\text { Comparison of } 2 \% \text { chlorhexidine and } 5.25 \% \text { sodium hypochlorite } \\
\text { irrigating solutions on postoperative pain: a randomized clinical } \\
\text { trial }\end{array}$ & $\begin{array}{c}\text { Not selected } \\
\text { Only one NaOCl } \\
\text { concentration }(5.25 \%)\end{array}$ \\
\hline $\begin{array}{l}\text { Haapasalo et al. }{ }^{24} \\
\text { Irrigation in endodontics }\end{array}$ & $\begin{array}{c}\text { Not selected } \\
\text { Review }\end{array}$ \\
\hline $\begin{array}{l}\text { Huffaker et al. } 25 \\
\text { Influence of a passive sonic irrigation system on the elimination of } \\
\text { bacteria from root canal systems: a clinical study }\end{array}$ & $\begin{array}{l}\text { Not selected } \\
\text { The same concentration o } \\
\text { o. } 5 \% \mathrm{NaOCl}\end{array}$ \\
\hline $\begin{array}{l}\text { Kandaswamy e Venkateshbabu }{ }^{26} \\
\text { Root canal irrigants }\end{array}$ & $\begin{array}{l}\text { Not selected } \\
\text { Review }\end{array}$ \\
\hline $\begin{array}{l}\text { Kaya et al. }{ }^{27} \\
\text { Evaluation of radicular dentin erosion and smear layer removal } \\
\text { capacity of self-adjusting file using different concentrations of } \\
\text { sodium hypochlorite as an initial irrigant }\end{array}$ & $\begin{array}{l}\text { Not selected } \\
\text { In vitro study }\end{array}$ \\
\hline $\begin{array}{l}\text { Paudel et al. } .^{28} \\
\text { Different pharmacological solutions in intracanal irrigation }\end{array}$ & $\begin{array}{l}\text { Not selected } \\
\text { Only one } \mathrm{NaOCl} \\
\text { concentration }\end{array}$ \\
\hline $\begin{array}{l}\text { Rôças e Siqueira Junior } 29 \\
\text { Comparison of the in vivo antimicrobial effectiveness of sodium } \\
\text { hypochlorite and chlorhexidine used as root canal irrigants: a } \\
\text { molecular microbiology study }\end{array}$ & $\begin{array}{c}\text { Not selected } \\
\text { Only one NaOCl } \\
\text { concentration }(2.5 \%)\end{array}$ \\
\hline $\begin{array}{l}\text { van der Vyver et al. } 3^{\circ} \\
\text { Antimicrobial efficacy of nine different root canal irrigation } \\
\text { solutions }\end{array}$ & $\begin{array}{l}\text { Not selected } \\
\text { Only one NaOCl } \\
\text { concentration }\end{array}$ \\
\hline $\begin{array}{l}\text { Beus et al. } .^{31} \\
\text { Comparison of the effect of two endodontic irrigation protocols on } \\
\text { the elimination of bacteria from root canal system: a prospective, } \\
\text { randomized clinical trial }\end{array}$ & $\begin{array}{l}\text { Not selected } \\
\text { Chlorexidine used }\end{array}$ \\
\hline $\begin{array}{l}\text { Keenan }{ }^{32} \\
\text { No evidence favouring one irrigant versus another in root canal } \\
\text { treatments }\end{array}$ & $\begin{array}{l}\text { Not selected } \\
\text { In vitro study }\end{array}$ \\
\hline $\begin{array}{l}\text { Pawar et al.33 } \\
\text { Influence of an apical negative pressure irrigation system on } \\
\text { bacterial elimination during endodontic therapy: a prospective } \\
\text { randomized clinical study }\end{array}$ & $\begin{array}{c}\text { Not selected } \\
\text { Only one } \mathrm{NaOCl} \\
\text { concentration }(0.5 \%)\end{array}$ \\
\hline $\begin{array}{l}\text { Cohenca et al. }{ }^{34} \\
\text { Antimicrobial efficacy of two irrigation techniques in tapered and } \\
\text { non-tapered canal preparations. A randomized controlled clinical } \\
\text { trial }\end{array}$ & $\begin{array}{c}\text { Not selected } \\
\text { Only one } \mathrm{NaOCl} \\
\text { concentration }(6 \%)\end{array}$ \\
\hline $\begin{array}{l}\text { Guo et al. } 35 \\
\text { Efficacy of four different irrigation techniques combined with } 60^{\circ} \mathrm{C} \\
3 \% \text { sodium hypochlorite and } 17 \% \text { EDTA in smear layer removal }\end{array}$ & $\begin{array}{l}\text { Not selected } \\
\text { In vitro study }\end{array}$ \\
\hline $\begin{array}{l}\text { Mashalkar et al. } 3^{6} \\
\text { Comparative evaluation of root canal disinfection by conventional } \\
\text { method and laser: an in vivo study }\end{array}$ & $\begin{array}{c}\text { Not selected } \\
\text { Only one NaOCl } \\
\text { concentration (3\%). }\end{array}$ \\
\hline $\begin{array}{l}\text { Martins et al. } 37 \\
\text { Outcome of Er,Cr:YSGG laser-assisted treatment of teeth with } \\
\text { apical periodontitis: a blind randomized clinical trial }\end{array}$ & $\begin{array}{c}\text { Not selected } \\
\text { Only one } \mathrm{NaOCl} \\
\text { concentration }(3 \%)\end{array}$ \\
\hline $\begin{array}{l}\text { Ma et al } 3^{8} \\
\text { The effects of sodium hypochlorite and chlorhexidine irrigants on } \\
\text { the antibacterial activities of alkaline media against Enterococcus } \\
\text { faecalis }\end{array}$ & $\begin{array}{l}\text { Not selected } \\
\text { In vitro study }\end{array}$ \\
\hline $\begin{array}{l}\text { Podar et al. }{ }^{39} \\
\text { In vivo antimicrobial efficacy of } 6 \% \text { Morinda citrifolia, Azadirachta } \\
\text { indica, and } 3 \% \text { sodium hypochlorite as root canal irrigants }\end{array}$ & $\begin{array}{c}\text { Not selected } \\
\text { Only one } \mathrm{NaOCl} \\
\text { concentration }(3 \%)\end{array}$ \\
\hline $\begin{array}{l}\text { Arias-Moliz et al. } 4^{0} \\
\text { Effects of dentin debris on the antimicrobial properties of sodium } \\
\text { hypochlorite and etidronic acid }\end{array}$ & $\begin{array}{l}\text { Not selected } \\
\text { In vitro study }\end{array}$ \\
\hline $\begin{array}{l}\text { 30. Rôças et al. } 41 \\
\text { Disinfecting effects of rotary instrumentation with either } 2.5 \% \\
\text { sodium hypochlorite or } 2 \% \text { chlorhexidine as the main irrigant: a } \\
\text { randomized clinical study }\end{array}$ & $\begin{array}{c}\text { Not selected } \\
\text { Only one } \mathrm{NaOCl} \\
\text { concentration }(2.5 \%)\end{array}$ \\
\hline $\begin{array}{l}\text { Kist et al.42 } \\
\text { Comparison of ozone gas and sodium hypochlorite/chlorhexidine } \\
\text { two-visit disinfection protocols in treating apical periodontitis: a } \\
\text { randomized controlled clinical trial }\end{array}$ & $\begin{array}{c}\text { Not selected } \\
\text { Only one } \mathrm{NaOCl} \\
\text { concentration }(3 \%)\end{array}$ \\
\hline $\begin{array}{l}\text { Nourzadeh et al. } 43 \\
\text { Comparative antimicrobial efficacy of Eucalyptus Galbie and Myrtus } \\
\text { Communis L. extracts, chlorhexidine and sodium hypochlorite } \\
\text { against Enterococcus Faecalis }\end{array}$ & $\begin{array}{l}\text { Not selected } \\
\text { In vitro study }\end{array}$ \\
\hline
\end{tabular}

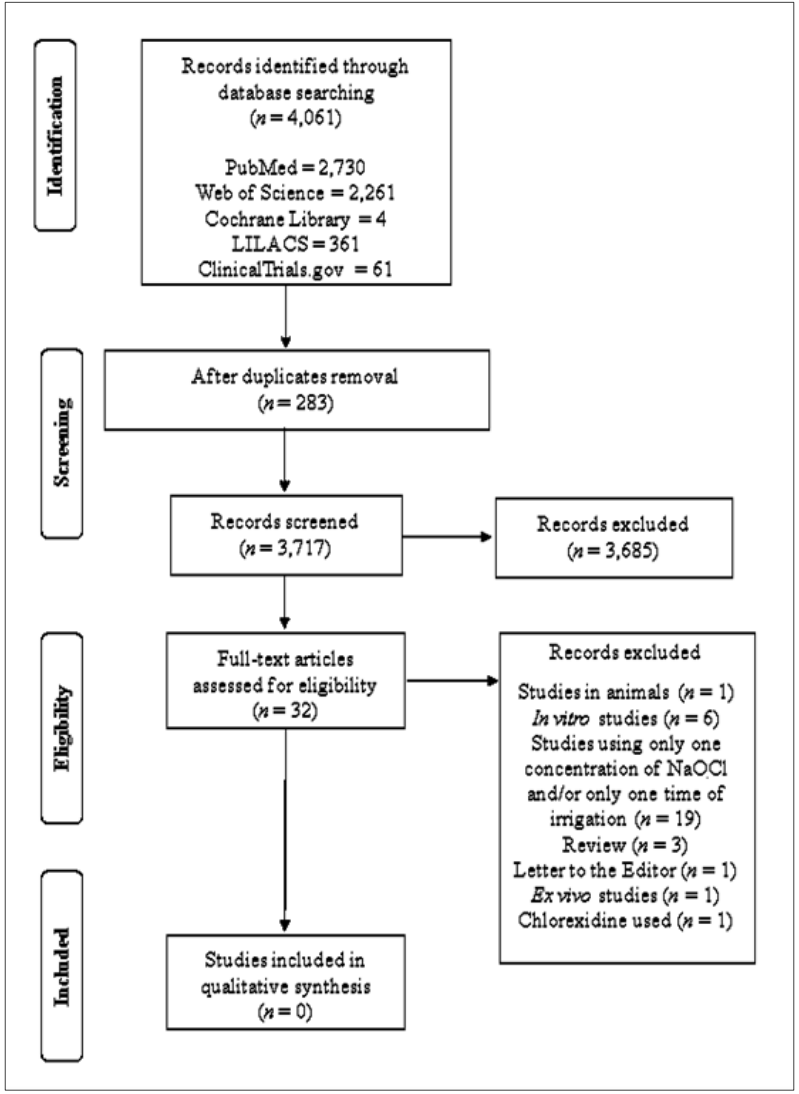

Figure 1: Flow chart showing the results of the search process.

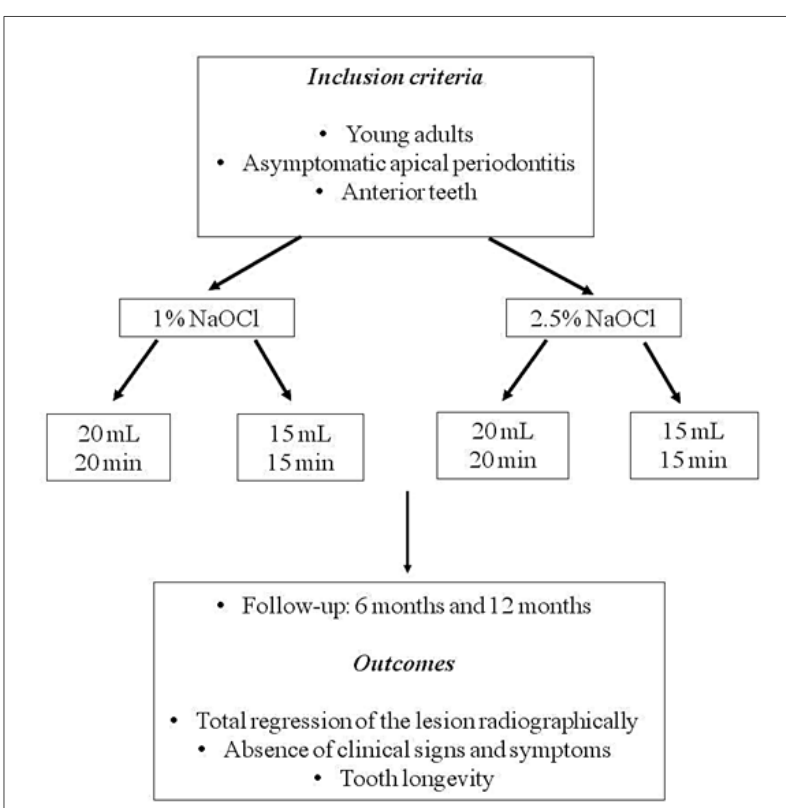

Figure 2: Flow chart suggesting controlled clinical investigations involving young adult patients with anterior teeth showing radiographically visible endodontic lesions using two options of $\mathrm{NaOCl}$ concentration, volume, and time of irrigation.

\section{DISCUSSION}

Sodium hypochlorite was first used by Henry Dakin in 1915 to clean wounds and its use in endodontics was suggested by Coolidge in 1919. In 1922, Walker proposed its use for the irrigation of root canals, with the procedure being later disseminated by Grossman ${ }^{44-46}$. Today, this is definitely the solution most extensively used 
worldwide for root canal instrumentation ${ }^{23}$. It is an alkaline solution with an approximate $\mathrm{pH}$ of 11 to 12 whose germicidal and antibacterial action has been demonstrated by many investigators ${ }^{30}$.

Although $\mathrm{NaOCl}$ has been part of the endodontic arsenal for more than one century, current investigations have been unable to determine the time of application, the volume or the concentration of this solution that can dissolve organic matter without weakening the dental structure during the phase of biomechanical preparation of the root canal. The present investigation was surprising by showing that no clinical trials on humans for the assessment of the concentrations, volumes and irrigation time with $\mathrm{NaOCl}$ solution were detected. And this result obligatorily stimulates the proposal of scientific methods that may resolve these questions.

Suggesting human studies that will provide an answer to this question is a challenge because of different variables. Other factors should be considered in addition to time of irrigation and concentration of the $\mathrm{NaOCl}$ solution ${ }^{10}$. Age-related structural changes in dentin may also be detrimental to its mechanical properties ${ }^{47}$ since dentin becomes dehydrated and therefore more fragile with age ${ }^{48}$. Gender has also been suggested to influence the number of roots and root canal system configuration in human permanent teeth. Thus, it is another variable that needs to be controlled in future trials ${ }^{49}$. Different endodontic diagnoses also need to be standardized in future studies since the time of regression of lesions such as periapical granulomas or cysts is longer than that for regression of only inflamed pulp.

Another provocative factor is the time of irrigation. Establishing the time necessary for the action of $\mathrm{NaOCl}$ during biomechanical preparation of the root canal system, i.e., 5, 10, 15, or 20 minutes as observational intervals, may render it enviable to obtain results due to aspects such as expertise of the clinicians and endodontists, the selection of endodontic systems, the protocols used, and patient collaboration. It should be pointed out, for example, that Nourzadeh et al. ${ }^{43}$ obtained an effective protocol by using $5.25 \% \mathrm{NaOCl}$ for 10 minutes. However, that was an in vitro study.

Also, the $\mathrm{NaOCl}$ concentrations used vary from values such as $0.5 \%$ (Dakin's fluid) ${ }^{4}, 1 \%$ (Milton's solution), 2.5\% (Labarraque's liquor), and 4 to $6 \%$ chlorinated soda $^{5,50}$. Different $\mathrm{NaOCl}$ irrigation protocols may alter the mechanical properties of dentin such as microhardness and modulus of elasticity ${ }^{51,52}$. NaOCl solutions of $5.25 \%$ have been shown to be potently antimicrobial in an in vitro study ${ }^{43}$ and in a clinical investigation by Paudel et $\mathrm{al}^{28}$. However, this result was obtained without a comparative analysis and using a reduced sample. Siqueira et al. ${ }^{53}$ demonstrated the killing efficacy of lower $\mathrm{NaOCl}$ concentrations, such as $4.0 \%$, against E. faecalis, and van der Vyver et al. ${ }^{30}$ demonstrated it using a $3.5 \%$ concentration. However, these were laboratory studies using isolated bacterial species. An effective antimicrobial action of $2.5 \% \mathrm{NaOCl}$ was detected in human trials, although the results were only compared to $0.2 \%$ or $0.12 \%$ chlorhexidine ${ }^{16,22}$ and to potassium iodide ${ }^{54}$. In contrast, according to a clinical study conducted by Gomes et al. ${ }^{21}$, a $2.5 \%$ $\mathrm{NaOCl}$ solution was ineffective in the elimination of endotoxins in primary infections of root canals of teeth with pulp necrosis and apical periodontitis.

Regarding the dissolution of organic tissue, there is no consensus about an ideal concentration for an effective action, although The ${ }^{15}$ proposed that 3\% $\mathrm{NaOCl}$ is the ideal concentration able to dissolve necrotic tissues. More recently, van der Vyver et al. ${ }^{30}$ stated that the irrigating solution is an ideal solvent of organic matter both for a vital and a necrotic pulp. However, they observed that this solution is intensely irritating for periapical tissues, especially at high concentrations. In our survey we did not detect comparative studies regarding different times and volumes of irrigation. Soares e Pires Júnior ${ }^{55}$, for example, compared three different concentrations $(1 \%, 2.5 \%$ and $5 \%)$ without varying time or volume. Podar et al. ${ }^{39}$ and Rôças et al. ${ }^{41}$ suggested a volume of $15 \mathrm{~mL}$ for the reduction of the number of aerobic and anaerobic bacteria per root canal.

The importance of the present investigation may perhaps reside in the feeling of absolute frustration it caused among the authors. The fact that there are no studies able to answer the key question leads us to suggest controlled clinical investigations involving young adult patients with anterior teeth showing radiographically visible endodontic lesions using two options of $\mathrm{NaOCl}$ concentration, volume, and time of irrigation, as shown in figure 2. After 12 years, Zehnder's ${ }^{5}$ comment that we are living in the age of evidence-based medicine, and any new concept or technique to be used in the clinic should ideally be assessed in randomized controlled trials is still timely and valid. This, however, represents a major problem in endodontic research.

\section{CONCLUSION}

This systematic review was unable to indicate what time of irrigation, concentration or volume of $\mathrm{NaOCl}$ solution can be of maximum effectiveness in endodontic treatment without causing significant changes in the mechanical properties of dentin. Thus, future controlled human clinical trials should be encouraged in view of the different factors that may bias and confuse the results.

\section{ACKNOWLEDGEMENT}

This work was supported by the Brazilian National Council for Scientific and Technological 
Development. The authors thank the Coordination for the Improvement of Higher Education Personnel (CAPES). Mrs. E. Greene provided English editing of the manuscript.

\section{REFERENCES}

1. Siqueira JF Jr, Guimarães-Pinto T, Rôças IN. Effects of chemomechanical preparation with $2.5 \%$ sodium hypochlorite and intracanal medication with calcium hydroxide on cultivable bacteria in infected root canals. J Endod. 2007;33(7):800-5.

2. Brito PR, Souza LC, Machado de Oliveira JC, Alves FR, De-Deus G, Lopes HP et al. Comparison of the effectiveness of three irrigation techniques in reducing intracanal Enterococcus faecalis populations: an in vitro study. J Endod. 2009;35(10):1422-27.

3. Baker NA, Eleazer PD, Averbach RE, Seltzer S. Scanning electron microscopic study of the efficacy of various irrigating solutions. J Endod. 1975; 1(4):127-35.

4. Bystrom A, Happonen RP, Sjogren U, Sundqvist G. Healing of periapical lesions of pulpless teeth after endodontic treatment with controlled asepsis. Endod Dent Traumatol. 1987;3(2):58-63.

5. Zehnder M. Root canal irrigants. J Endod. 2006; 32(5):389-98.

6. Türkün M, Cengiz T. The effects of sodium hypochlorite and calcium hydroxide on tissue dissolution and root canal cleanliness. Inter Endod J. 1997;30(5):335-42.

7. Naenni N, Thoma K, Zehnder M. Soft tissue dissolution capacity of currently used and potential endodontic irrigants. J Endod. 2004; 30(11):785-87.

8. Clarkson RM, Moule AJ, Podlich H, Kellaway R, Macfariane R, Lewis D. Dissolution of porcine incisor pulps in sodium hypochlorite solutions of varying compositions and concentrations. Aust Dent J. 2006;51(3):245-51.

9. Siqueira JF Jr, Rôças IN, Favieri A, Lima KC. Chemomechanical reduction of the bacterial population in the root canal after instrumentation and irrigation with $1 \%, 2.5 \%$, and $5.25 \%$ sodium hypochlorite. J Endod. 2000;26(6):331-34.

10.Gu LS, Huang XQ, Griffin B, Bergeron BR, Pashley DH, Niu LN et al. Primum non nocere The effects of sodium hypochlorite on dentin as used in endodontics. Acta Biomater. 2017; 61:144-56.

11. Barreto MS, Moraes Rdo A, Rosa RA, Moreira $\mathrm{CH}$, Só MV, Bier CA. Vertical root fractures and dentin defects: effects of root canal preparation, filling, and mechanical cycling. J Endod. 2012; 38(8):1135-39.

12. Chai $\mathrm{H}$, Tamse A. The effect of isthmus on vertical root fracture in endodontically treated teeth. J Endod. 2015;41(9):1515-19.

13. Moher D, Liberati A, Tetzlaff J, Altman DG, PRISMA Group. Preferred reporting items for systematic reviews and meta-analyses: the PRISMA statement. J Clin Epidemiol. 2009; 62(10):1006-12.

14. Hand RE, Smith ML, Harrison JW. Analysis of the effect of dilution on the necrotic tissue dissolution property of sodium hypochlorite. J Endod. 1978; 4(2):60-4.

15.Thé SD. The solvent action of sodium hypochlorite on fixed and unfixed necrotic tissue. Oral Surg Oral Med Oral Pathol. 1979;47(6):558-61.

16. Ringel AM, Patterson SS, Newton CW, Miller $\mathrm{CH}$, Mulhern JM. In vivo evaluation of chlorhexidine gluconate solution and sodium hypochlorite solution as root canal irrigants. J Endod.1982;8(5):200-4.

17.Ercan E, Ozekinci T, Atakul F, Gül K. Antibacterial activity of $2 \%$ chlorhexidine gluconate and $5.25 \%$ sodium hypochlorite in infected root canal: in vivo study. J Endod.2004;30(2):84-7.

18.Siqueira JF Jr, Rôças IN, Paiva SS, GuimarãesPinto T, Magalhães KM, Lima KC. Bacteriologic investigation of the effects of sodium hypochlorite and chlorhexidine during the endodontic treatment of teeth with apical periodontitis. Oral Surg Oral Med Oral Pathol Oral Radiol Endod. 2007;104(1),122-30.

19.Estrela C, Silva JA, de Alencar AH, Leles CR, Decurcio DA. Efficacy of sodium hypochlorite and chlorhexidine against Enterococcus faecalis-a systematic review. J Appl Oral Sci.2008;16(6):364-68.

20.Fedorowicz Z, Sequeira P. Efficacy of sodium hypochlorite and chlorhexidine against Enterococcus faecalis--a systematic review. J Appl Oral Sci.2008;16(6):364-68.

21.Gomes BP, Martinho FC, Vianna ME. Comparison of $2.5 \%$ sodium hypochlorite and $2 \%$ chlorhexidine gel on oral bacterial lipopolysaccharide reduction from primarily infected root canals. J Endod; 2009; 35(10):1350-53.

22. Abbaszadegan A, Khayat A, Motamedifar M. Comparison of antimicrobial efficacy of IKI and $\mathrm{NaOCl}$ irrigants in infected root canals: an in vivo study. Iran Endod J.2010;5(3):101-6.

23. Bashetty K, Hegde J. Comparison of $2 \%$ chlorhexidine and $5.25 \%$ sodium hypochlorite irrigating solutions on postoperative pain: a randomized clinical trial. Indian $\mathbf{J}$ Dent Res.2010;21(4):523-27.

24. Haapasalo M, Shen Y, Qian W, Gao Y. Irrigation in endodontics. Dent Clin North Am. 2010;54(2):291-312.

25.Huffaker SK, Safavi K, Spangberg LS, Kaufman B. Influence of a passive sonic irrigation system 
on the elimination of bacteria from root canal systems: a clinical study. J Endod. 2010;36(8):1315-18.

26. Kandaswamy D, Venkateshbabu N. Root canal irrigants. J cons dent.2010;13(4),256-64.

27.Kaya S, Yiğit-Özer S, Adigüzel O. Evaluation of radicular dentin erosion and smear layer removal capacity of self-adjusting file using different concentrations of sodium hypochlorite as an initial irrigant. Oral Surg Oral Med Oral Pathol Oral Radiol and Endod.2011;112(4):524-30.

28.Paudel KR, Jaiswal A, Parajuli U, Bajracharya M. Different pharmacological solutions in intracanal irrigation. Nepal Med Coll J. 2011;13(2):111-14.

29.Rôças IN, Siqueira JF Jr. Comparison of the in vivo antimicrobial effectiveness of sodium hypochlorite and chlorhexidine used as root canal irrigants: a molecular microbiology study. J Endod.2011;37(2):143-50.

30.van der Vyver PJ, Botha FS, de Wet FA. Antimicrobial efficacy of nine different root canal irrigation solutions. SADJ. 2014; 69(4):15860,162-65.

31.Beus C, Safavi K, Stratton J, Kaufman B (2012) Comparison of the effect of two endodontic irrigation protocols on the elimination of bacteria from root canal system: a prospective, randomized clinical trial. J Endod. 2012; 38(11):1479-83.

32. Keenan AV. No evidence favouring one irrigant versus another in root canal treatments. Evid Based Dent.2012; 13(4):107.

33.Pawar R, Alqaied A, Safavi K, Boyko J, Kaufman B. Influence of an apical negative pressure irrigation system on bacterial elimination during endodontic therapy: a prospective randomized clinical study. J Endod.2012;38(9):1177-81.

34. Cohenca N, Paranjpe A, Heilborn C, Johnson JD. Antimicrobial efficacy of two irrigation techniques in tapered and non-tapered canal preparations. A randomized controlled clinical trial. Quintessence Int. 2013;44(3):217-28.

35. Guo X, Miao H, Li L, Zhang S, Zhou D, Lu Y, $\mathrm{Wu}$ L. Efficacy of four different irrigation techniques combined with $60{ }^{\circ} \mathrm{C} 3 \%$ sodium hypochlorite and 17\% EDTA in smear layer removal. BMC Oral Health. 2014;14:114.

36. Mashalkar S, Pawar MG, Kolhe S, Jain DT. Comparative evaluation of root canal disinfection by conventional method and laser: an in vivo study. Niger J Clin Pract. 2014;17(1):67-74.

37. Martins MR, Carvalho MF, Pina-Vaz I, Capelas JA, Martins MA, Gutknecht N. Outcome of Er,Cr:YSGG laser-assisted treatment of teeth with apical periodontitis: a blind randomized clinical trial. Photomed Laser Surg. 2014;32(1):3-9.

38. Ma J, Tong Z, Ling J, Liu H, Wei X. The effects of sodium hypochlorite and chlorhexidine irrigants on the antibacterial activities of alkaline media against Enterococcus faecalis. Arch Oral Biol.2015;60(7):1075-81.

39.Podar R, Kulkarni GP, Dadu SS, Singh S, Singh SH. In vivo antimicrobial efficacy of $6 \%$ Morinda citrifolia, Azadirachta indica, and 3\% sodium hypochlorite as root canal irrigants. Eur J Dent.2015;9(4):529-34.

40.Arias-Moliz MT, Morago A, Ordinola-Zapata R, Ferrer-Luque CM, Ruiz-Linares $M$, Baca $P$. Effects of dentin debris on the antimicrobial properties of sodium hypochlorite and etidronic acid. J Endod. 2016;42(2):771-75.

41.Rôças IN, Provenzano JC, Neves MA, Siqueira JF Jr. Disinfecting effects of rotary instrumentation with either $2.5 \%$ sodium hypochlorite or $2 \%$ chlorhexidine as the main irrigant: a randomized clinical study. J Endod. 2016;42(6):943-47.

42.Kist S, Kollmuss M, Jung J, Schubert S, Hickel R, Huth KC. Comparison of ozone gas and sodium hypochlorite/chlorhexidine two-visit disinfection protocols in treating apical periodontitis: a randomized controlled clinical trial. Clin Oral Investig. 2017;21(4):995-1005.

43. Nourzadeh M, Amini A, Fakoor F, Raoof M, Sharififar F. Comparative antimicrobial efficacy of Eucalyptus Galbie and Myrtus Communis L. extracts, chlorhexidine and sodium hypochlorite against Enterococcus Faecalis. Iran Endod J.2017.12(2):205-10.

44.Dakin HD. On the use of certain antiseptic substances in the treatment of infected wounds. $\mathrm{Br}$ Med J. 1915; 2(2852):318-20.

45. Walker A. A definite and dependable therapy for pulpless teeth. J Am Dent Assoc. 1922; 23(8):1418-25.

46. Grossman LI. Irrigation of root canals. J Am Dent Assoc. 1943;30:1915-17.

47.Bajaj D, Sundaram N, Nazari A, Arola D. Age, dehydration and fatigue crack growth in dentin. Biomaterials. 2006;27(11):2507-17.

48. Kruzic JJ, Nalla RK, Kinney JH, Ritchie RO. Crack blunting, crack bridging and resistancecurve fracture mechanics in dentin: effect of hydration. Biomaterials. 2003;24(28):5209-21.

49. Martins JNR, Marques D, Francisco H, Caramês $\mathrm{J}$. Gender influence on the number of roots and root canal system configuration in human permanent teeth of a Portuguese subpopulation. Quintessence Int. 2018;49(2):103-11.

50.Zehnder M, Schmidlin P, Sener B, Waltimo T. Chelation in root canal therapy reconsidered. J Endod. 2005;31(11):817-20.

51.Marending M, Luder HU, Brunner TJ, Knecht S, Stark WJ, Zehnder M. Effect of sodium hypochlorite on human root dentine-mechanical, chemical and structural evaluation. Int Endod J. 2007;40(10):786-93. 
52. Aslantas EE, Buzoglu HD, Altundasar E, Serper A. Effect of EDTA, sodium hypochlorite, and chlorhexidine gluconate with or without surface modifiers on dentin microhardness. J Endod. 2014; 40(6):876-79.

53. Siqueira JF Jr, Machado AG, Silveira RM, Lopes HP, de Uzeda M. Evaluation of the effectiveness of sodium hypochlorite used with three irrigation methods in the elimination of Enterococcus faecalis from the root canal, in vitro. Int Endod J. 1997; 30(4):279-82.

54. Hertel M, Sommer K, Kostka E, Imiolczyk SM, Ballout H, Preissner S. Outcomes of endodontic therapy comparing conventional sodium hypochlorite irrigation with passive ultrasonic irrigation using sodium hypochlorite and ethylenediaminetetraacetate. A retrospective analysis. Open Dent J. 2016; 10:375-81.

55. Soares JA, Pires Júnior DR. Influence of sodium hypochlorite-based irrigants on the susceptibility of intracanal microbiota to biomechanical preparation. Braz Dent J. 2006; 17(4):310-6.

\section{CONFLICTS OF INTERESTS}

The authors declare no conflicts of interests.

\section{CORRESPONDING AUTHOR}

\section{Amália Moreno}

amalia_moreno@yahoo.com.br

Received 22/08/2018

Accepted 04/10/2018 